Матеріали Всеукраїнської науково-практичної конференчії «Актуальні питання діагностики, лікування, раціональної фармакотерапії, диспансеризації та реабілітації в практичі сімейного лікаря"

DOI

\title{
РОЛЬ АДИПОКІНІВ ЖИРОВОЇ ТКАНИНИ У ПРОГРЕСУВАННІ БРОНХІАЛЬНОЇ АСТМИ У ХВОРИХ 3 ОЖИРІННЯМ
}

๑л. М. Пасієшвілі, Т. М. Пасієшвілі

Харківський національний медичний університет, Україна

Вступ. Бронхіальна астма (БА) належить до хронічних рецидивуючих захворювань внутрішніх органів, що має спадкову схильність, тобто її формування та перебіг $\epsilon$ генетично зумовленим. Поєднання БА з іншими неінфекційними захворюваннями внутрішніх органів доволі часто обумовлює тяжкий перебіг, що проявляється формуванням рефрактерних до загальновизнаної терапії форм. До захворювань, вплив яких може призвести до розвитку ускладнень, належить ожиріння.

На теперішній час ожиріння розглядають у контексті самостійної хвороби з метаболічними наслідками, а жирову тканину - як ендокринний орган, що продукує багато активних речовин. Приєднання ожиріння у хворих на БА в такому разі додає не тільки механічних перешкод, які виникають внаслідок зменшення екскурсії діафрагми та навантаження загальною масою тіла, але й сприяє накопиченню в організмі адипокінів (ІЛ-1, ФНП-а, лептину, резистину, апеліну тощо), які можуть підтримувати запальний процес у бронхолегеневій системі. Тобто можна припустити, що загострення БА у хворих з ожирінням не завжди пов'язане 3 несприятливими позалегеневими умовами (інфекційні агенти), а іï̈ перебіг, формування тяжких форм та ускладнень може бути результатом ендокринної активності жирової тканини.

Метою роботи було визначення стану окремих адипокінів жирової тканини у хворих на БА, що перебігає на тлі ожиріння.

Матеріали та методи дослідження. Під наглядом було 37 хворих на БА в стані ремісії захворювання віком від 23 до 47 років з тривалістю захворювання від 4 до 16 років. Переважали жінки - 77,4 \%. У 21 випадку БА перебігала на тлі ожиріння 1 (12 осіб) або 2 (8) ступеня тяжкості основна група. 16 пацієнтів мали нормальну масу тіла та увійшли до групи порівняння. Результати контрольних досліджень були отримані у 20 практично здорових осіб. Всі групи обстежених були репрезентативні за віком і статтю.
У сироватці досліджених пацієнтів визначали вміст показників ФНП-а, ІЛ-6 методом ІФА з використанням набору реактивів «Про-контур» (СПб., Росія).

Показник вмісту резистину - імуноферментним сандвіч-методом, набір реактивів «Віо Vendor", Чеська республіка.

Статистичну обробку результатів проводили за допомогою пакетів програм BIOSTAT версія 4.03 і STATISTICA версія 6.1.

Результати й обговорення. При визначенні показника ФНП-а було встановлено, що у хворих основноїгрупийоговміст дорівнював $(36,9 \pm 2,1) \mathrm{Hг} / л$ проти групи порівняння - $(27,1 \pm 1,5) \mathrm{Hг} / л$ та показників контролю $(24,2 \pm 1,6)$ нг/л. Вміст ІЛ-6 також мав суттєві відмінності в основній групі хворих та становив $(43,9 \pm 2,1)$ нг/л; в групі хворих на ізольовану БА - $(33,2 \pm 2,1)$ нг/л (показник норми $(31,4 \pm 2,3)$ нг/л). Вміст резистину в сироватці крові хворих основної групи перевищував показник норми в 1,4 раза та в групі порівняння не мав сут-

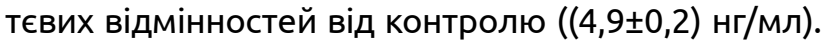
Досліджені показники ІЛ-6, ФНП-а та резистину не мали залежності від статі, тривалості основного захворювання та стадії ожиріння, що, мабуть, в деяких моментах може бути наслідком невеликої кількості хворих. Таким чином, клінічна ремісія БА у хворих з ожирінням не супроводжується позитивною лабораторною динамікою, а остаточні результати адипокінового спектра жирової тканини можуть тривалий час підтримували активний запальний процес в організмі.

Висновки. Перебіг БА у хворих з ожирінням супроводжується тривалими лабораторними змінами показників адипокінового спектра крові, що обумовлює латентний запальний процес в організмі. Означені запальні зміни можуть сприяти формуванню тяжких форм захворювання, що потребує ретельного спостереження за хворими 3 БА та ожирінням. 